\title{
IMPLEMENTASI ALGORITMA APRIORI DALAM MENENTUKAN PERSEDIAAN OBAT
}

\author{
Gusti Ahmad Syaripudin 1), Edi Faizal ${ }^{2)}$ \\ 1) Teknik Informatika STMIK El Rahma Yogyakarta \\ ${ }^{1)}$ Jl. Sisingamangaraja No. 76, Karangkajen, Brontokusuman, Mergangsan, Yogyakarta 55153 \\ ${ }^{2)}$ Manajemen Informatika STMIK Akakom Yogyakarta \\ 2) J1. Raya Janti Karang Jambe No. 143 Yogyakarta 55198, Indonesia \\ e-mail: first234boy@gmail.com ${ }^{1)}$, edifaizal@akakom.ac.id ${ }^{2)}$
}

\begin{abstract}
ABSTRAK
Transaksi berbasis komputer menyebabkan penumpukkan data dalam basis data sebuah aplikasi. Data tersebut dapat diolah kembali untuk mendapatkan informasi yang sangat penting. Penambangan data (data mining), dapat digunakan untuk mendapatkan informasi penting tersebut untuk keperluan manajemen. Teknik yang dapat digunakan adalah aturan asosiasi. Salah satu jenis aturan asosiasi adalah algoritma apriori. Penerapan algoritma apriori sudah banyak dilakukan dalam analisis penjualan. Pada penelitian akan diterapkan pada aplikasi apotek RMC. Bahasa pemrograman yang digunakan untuk implementasi algoritma tersebut adalah bahasa Java dengan Platform Netbeans 7.4 .DBMS yang digunakan adalah MySQL. Hasil pengujian menunjukan algoritma apriori dapat digunakan untuk mengidentifikasi obat yang kemungkinan dibeli bersamaan dengan obat lain, serta menunjukkan obat yang paling banyak dan paling sedikit terjual berdasarkan himpunan kombinasi item. Rekomendasi tersebut dapat digunakan pihak manajemen dalam menentukan persediaan obat dan merancang strategi pemasaran dengan cepat, tepat dan efisien.
\end{abstract}

Kata kunci : java, algoritma apriori, netbeans, $M y S Q L$

\begin{abstract}
Computer-based transaction resulting in the accumulation of data in the database of an application. The data can be reprocessed to obtain important information. Data mining can be used to obtain valuable information for management purposes. The technique can be used are the rules of the association. One type of association rules is a priori algorithm. Application of a priori algorithm has been done in the analysis of sales. The research will be applied to the application pharmacies RMC. The programming language used for the algorithm implementation language is Java with Netbeans Platform 7.4 .DBMS used is MySQL. The test results showed a priori algorithm can be used to identify drugs that may be purchased in conjunction with other drugs, as well as showing the drug most widely sold and least by the set of combinations of items. Such recommendations can be used for management in determining drug supply and design marketing strategies quickly, accurately and efficiently.
\end{abstract}

Keywords: java, apriori algorithm, netbeans, $M y S Q L$

\section{PENDAHULUAN}

$\mathrm{P}$ ersaingan dalam bidang ekonomi mempunyai dampak terhadap berkembangnya kreatifitas dan inovasi dalam penjualan. Salah satu dari inovasi yang sering digunakan pada masa kini adalah penggunaan sistem komputerisasi dalam penjualan produk baik berbasis online maupun offline. Salah satu metode yang dapat digunakan untuk menganalisis pola perilaku belanja konsumen adalah analisis keranjang belanja atau Market Basket Analysis (MBA). Analisis ini merupakan salah satu metode dalam penambangan data (data mining) yang bertujuan untuk menemukan produk-produk yang sering dibeli bersamaan dari data transaksi. Metode analisa pola perilaku belanja $M B A$ menggunakan bantuan algoritma apriori, yang merupakan algoritma $M B A$ yang digunakan untuk menghasilkan association rule, dengan pola "if-then". Teknik tersebut dapat diterapkan seperti pada data transaksi penjualan [1].

Apotek RMC (Rizqi Media Center) adalah sebuah badan usaha yang bergerak dalam bidang penjualan obat-obatan dan pelayanan pengobatan bagi masyarakat umum. Dikarenakan badan usaha ini masih baru berjalan maka dibuatlah analisa dalam penanganan data dan dalam pengambilan keputusan untuk menyuplai obat-obatan. Pada dasarnya pihak apotek RMC belum menerapkan sistem menganalisis data secara spesifik seperti pengkombinasian item sehingga tidak diketahui bagaimana hubungan antar suatu item dengan item yang lain. Selain itu untuk mengetahui produk-produk yang paling banyak terjual masih dilakukan dengan menganalisis data secara manual yang memerlukan waktu yang lama dan ketelitian. Tentu cara ini sangatlah menguras waktu dan tenaga.

Data mining didefinisikan sebagai sebuah proses untuk menemukan hubungan, pola dan trend baru yang bermakna dengan menyaring data yang sangat besar, yang tersimpan dalam penyimpanan, menggunakan teknik pengenalan pola seperti teknik statistik dan matematika [2]. Data mining adalah proses mengekstrasi informasi atau sesuatu yang penting atau menarik dari data yang ada di dalam database sehingga menghasilkan informasi 
yang sangat berharga. Tenik analisa keranjangm pasar merupakan teknik yang mengadaptasi ilmu data mining.Teknik ini digunakan untuk merancang suatu strategi penjualan dan pemasaran barang melalui proses pencarian asosiasi atau hubungan antar item data dari suatu basis data relasional [3].

Algoritma apriori termasuk jenis aturan asosiasi pada data mining (lihat Gambar 1). Selain apriori, yang termasuk pada golongan ini adalah metode Generalized Rule Induction dan Algoritma Hash Based. Aturan yang menyatakan asosiasi antara beberapa atribut sering disebut affinity analysis atau market basket analysis [4]. Analisis asosiasi atau association rule adalah teknik data mining untuk menemukan aturan asosiatif antara suatu kombninasi item. Algoritma Apriori yang bertujuan untuk menemukan frequent itemsets dijalankan pada sekumpulan data. Analaisis Apriori didefenisikan suatu proses untuk menemukan semua aturan apriori yang memenuhi syarat minimum untuk support dan syarat minimum untuk confidence.

\section{METODE}

Dalam penelitian ini dilakukan beberapa metode untuk memperoleh data, mengolah data, serta penggunaan perangkat dalam menyelesaikan permasalahan. Adapun metode yang dilakukan adalah :

\section{A. Metode pengumpulan data}

Dalam melakukan pengumpulan data perlu melakukan metode-metode tertentu agar mendapatkan data yang sesuai dengan kebutuhan. Metode yang dilakukan dalam penelitian ini yaitu:

1) Metode observasi. Penulis melakukan pengamatan secara langsung pada objek yang diteliti dan dicatat secara sistematis berdasarkan fakta yang ada pada Klinik Pratama Rizqi Medical Center (RMC).

2) Metode wawancara. Pada tahap ini dilakukan wawancara kepada pemilik Klinik Pratama dengan mengajukan beberapa pertanyaan sesuai kebutuhan data yang diperlukan.

3) Metode kepustakaan. Metode kepustakaan dilakukan dengan cara mengumpulkan referensi baik dari buku, artikel, paper, jurnal mengenai algoritma apriori.

B. Metode perancangan sistem

Dalam metode ini dilakukan analisis kebutuhan, perancangan sistem, implementasi dan evaluasi sistem.

1) Analisis kebutuhan. Menganalisa input dan output apa saja yang akan dilakukan untuk pembuatan sistem.

2) Perancangan sistem. Perancangan sistem merupakan tahapan yang dilakukan untuk membuat sebuah rancangan program berdasarkan input dan output yang diinginkan.

3) Implementasi sistem. Setelah pembuatan perancangan sistemmakalangkah selanjutnya adalah mengimplementasikan hasil perancangan ke dalam program (MySQL, Java Netbeans).

4) Evaluasi sistem. Evaluasi merupakan langkah setelah data di entry kemudian di simpan dan dicetak, untuk mengetahui kesalahan yang mungkin terjadi, sampai dipastikan sistem dapat berjalan dengan sempurna.

\section{Metode Implementasi Algoritma Apriori}

Algoritma Apriori menggunakan pengetahuan frekuensi atribut yang telah diketahui sebelumnya untuk memproses informasi selanjutnya. Pada algoritma Apriori menentukan kandidat yang mungkin muncul dengan cara memperhatikan minimum support dan minimum confidence. Support adalah nilai pengunjung atau persentase kombinasi sebuah item dalam database. Sedangkan confidence adalah nilai kepastian yaitu kuatnya hubungan antar item dalam sebuah Apriori. Confidence dapat dicari setelah pola frekuensi munculnya sebuah item ditemukan. Proses utama yang dilakukan dalam algoritma Apriori untuk mendapat frequent itemset yaitu:

1) Join (penggabungan), proses ini dilakukan dengan cara pengkombinasian item dengan item yang lainnya hingga tidak dapat terbentuk kombinasi lagi.

2) Prune (pemangkasan), proses pemangkasan yaitu hasil dari item yang telah dikombinasikan kemudian dipangkas dengan menggunakan minimum support yang telah ditentukan oleh user.

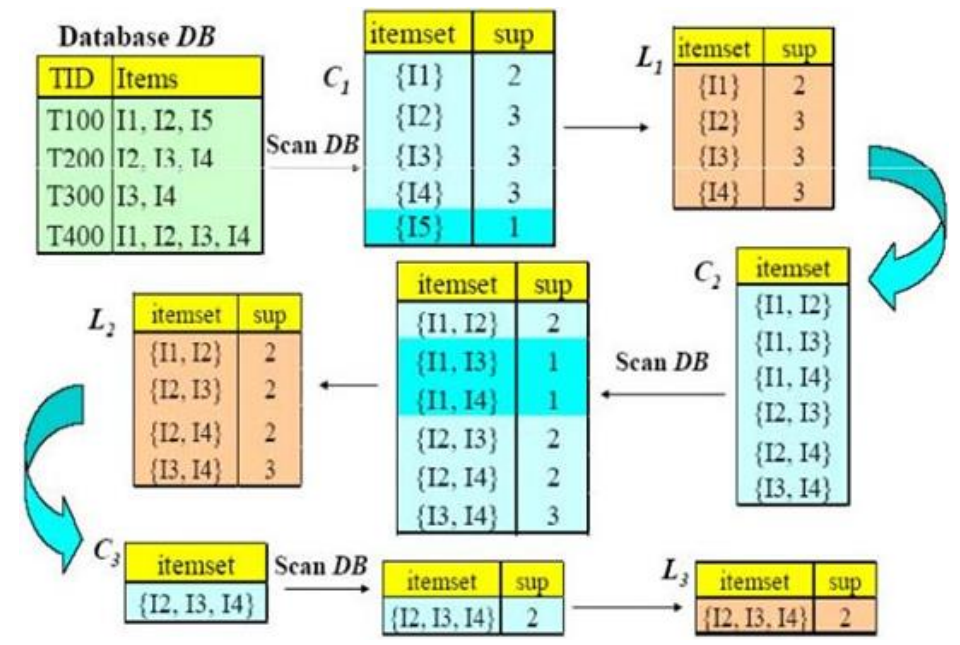




\section{Metode Analisis Aturan Asosiasi}

Analisis asosiasi dikenal juga sebagai salah satu teknik Data mining yang menjadi dasar dari berbagai teknik Data mining lainnya. Khususnya salah satu tahap dari analisis asosiasi yang disebut analisis pola frequensi tinggi (frequent pattern mining) menarik perhatian banyak peneliti untuk menghasilkan algoritma yang efisien. Metodologi dasar analisis asosiasi terbagi menjadi dua tahap yaitu [5] :

1) Analisa pola frekuensi tinggi

Tahap ini mencari kombinasi item yang memenuhi syarat minimum dari nilai support dalam database. Nilai support sebuah item diperoleh dengan Persamaan (1).

$$
\text { Support (A) }=\frac{\text { JmlTransaksiMengandung A }}{\text { TotalTransaksi }}
$$

sedangkan nilai support dari 2 item diperoleh dari Persamaan (2).

$$
\text { Support }(\mathrm{A}, \mathrm{B})=P(A \cap B) \frac{\text { JmlTransaksiMengandung } A \text { dan } B}{\text { TotalTransaksi }}
$$

2) Pembentukan aturan assosiatif

Setelah semua pola frekuensi tinggi ditemukan, barulah dicari aturan assosiatif yang memenuhi syarat minimum untuk confidence dengan menghitung confidence aturan assosiatif $\mathrm{A}$, B Nilai confidence dari aturan $\mathrm{A}$ ` B diperoleh dari Persamaan (3).

$$
\text { Confidence }=\mathrm{P}(\mathrm{A} \mid \mathrm{B})=\frac{\text { JmlTransaksiMengandung } \mathrm{A} \text { dan } B}{\text { JmlTotalTransaksi } A}
$$

\section{HASIL}

Implementasi merupakan tahapan setelah melakukan perancangan sistem pada siklus rekayasa perangkat lunak dimana aplikasi siap dioperasikan pada keadaan yang sebenarnya dengan tujuan mengubah hasil dari rancangan sistem menjadi bentuk nyata. Pada tahap ini dapat diketahui apakah aplikasi yang telah dibuat benar-benar dapat menghasilkan keluaran yang sudah sesuai dengan apa yang telah dirancang sebelumnya.

Berdasarkan hasil perancangan yang telah dibuat maka dilakukan implementasi yang akan menghasilkan sebuah aplikasi penjualan dan analisis algoritma apriori. Untuk dapat menjalankan apikasi ini maka terlebih dahulu menginstal aplikasi WampServer. Form Utama merupakan bagian utama dari aplikasi ini, dimana seluruh kegiatan yang dilakukan dalam pengoperasian dari sistem difokuskan pada bagian ini. Form Utama dapat dilihat pada Gambar 2.

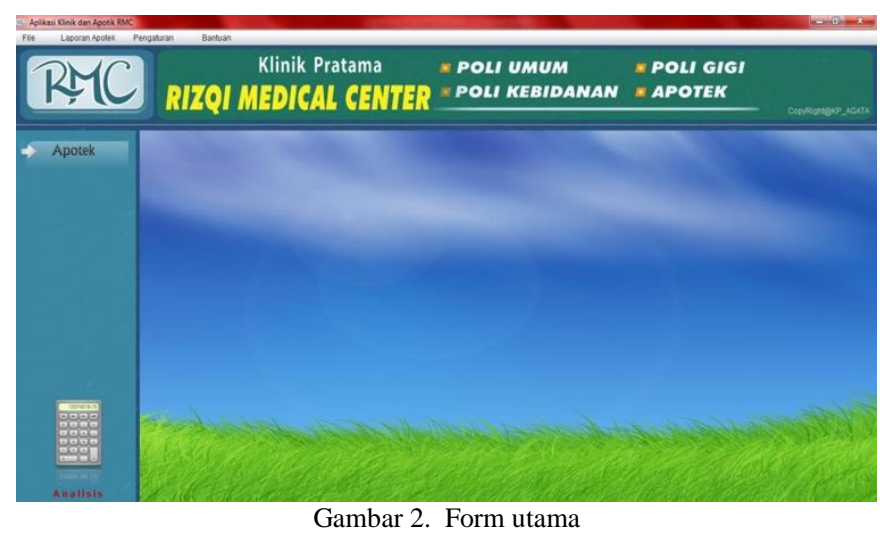

Form Analisis adalah form yang memuat tentang analisis data dengan algoritma apriori. Penting tidaknya suatu aturan assosiatif dapat diketahui dengan dua parameter, support (nilai penunjang) yaitu persentase kombinasi item tersebut dalam database dan confidence (nilai kepastian) yaitu kuatnya hubungan antar item dalam aturan asosiasi.

Dari berbagai pernyataan yang telah disebutkan diatas, dalam aplikasi Apotek RMC ini telah menerapkan aturan asosiasi tersebut untuk menganalisa data penjualan. Penerapan analisis asosiasi dapat dilihat pada form Analisis. Form Analisis tampilannya dapat dilihat pada Gambar 3. 


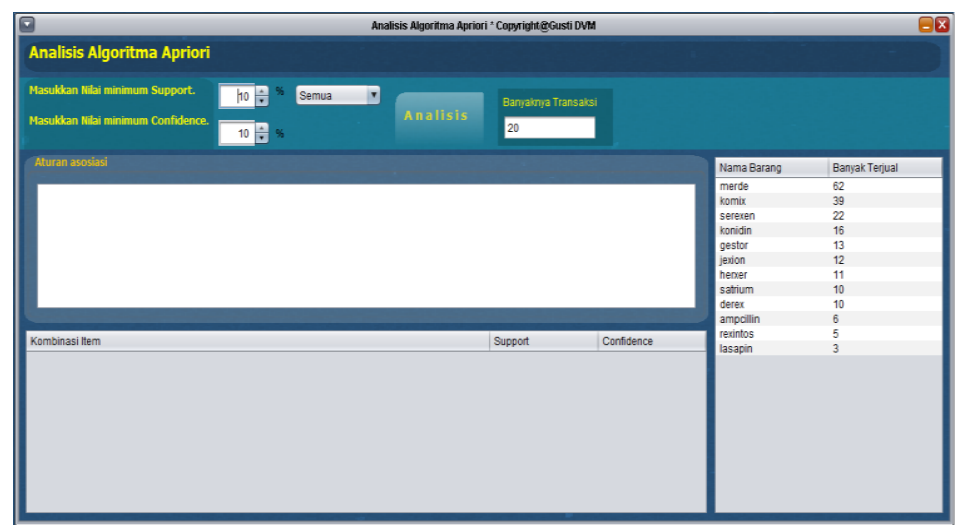

Gambar 3. Form Analisis

Analisis dilakukan dengan mengklik tombol Analisis. Berdasarkan inputan pada kolom minimum Support dan kolom minimum Confidence serta pilihan menu, maka sistem akan melakukan scan pada database dan menampilkan hasilnya pada kolom Aturan Asosiasi dan tabel Asosiasi (lihat Gambar 4).

Misalkan pada pernyataan "Jika membeli "herxer" maka akan membeli "merde" dengan Supp 15\% dan Conf $50 \%$ " yang artinya kombinasi antara herxer dengan merde memiliki nilai support sebesar $15 \%$ dan nilai confidence sebesar 50\%. Penyederhanaan dari pernyataan ini yaitu dapat dikatakan bahwa "50\% dari transaksi di database yang memuat item herxer juga memuat item merde. Sedangkan $15 \%$ dari seluruh transaksi di database memuat kedua item itu."

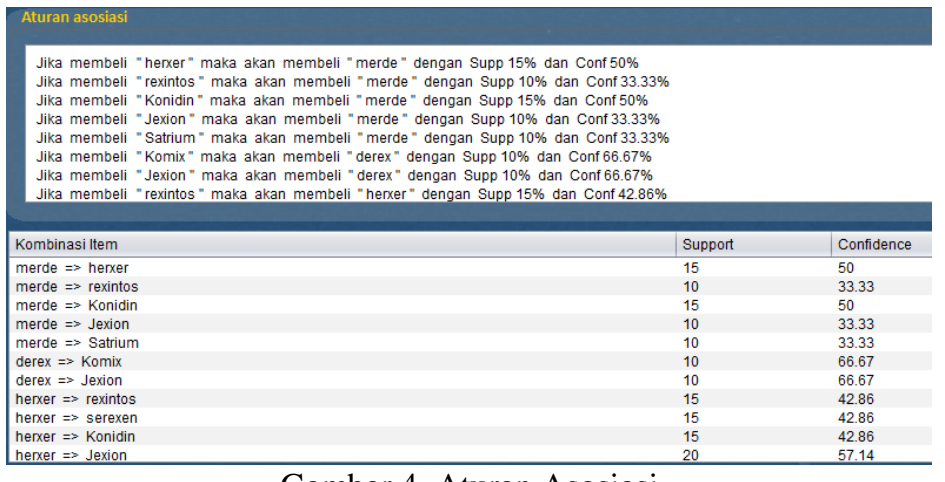

Gambar 4. Aturan Asosiasi

\section{PEMBAHASAN}

Hasil penelitian menunjukan bahwa sistem dapat mengidentifikasi obat yang kemungkinan dibeli bersamaan dengan obat lain, serta menunjukkan obat yang paling banyak terjual dan paling sedikit terjual. Cara membuktikan keakuratan sistem ini dapat diketahui dengan langkah-langkah perhitungan berikut.

1) Gunakan pernyataan "Jika membeli “ herxer” maka akan membeli „merde" dengan Supp 15\% dan Conf $50 \% "$.

2) Gunakan query untuk mencari jumlah kombinasi dua item (lihat Gambar 5.68) maka item a = „220440000"

karena merupakan kode obat merde, dan item $b=, 220440002^{* e}$ yang merupakan kode obat herxer. Jadi querynya adalah :

"select COUNT (DISTINCT no_nota) as ddd from transaksi_apotik_detail where no_nota in ( select no_nota from transaksi_apotik_detail where $k d \_o b a t=' 220440000$ ' ) and no_nota in (select no_nota from transaksi_apotik_detail where $k d \_o b a t=$ '220440002' )"

3) Masukkan ke dalam SQL pada database "rmc" di MySQL. Dari eksekusi query pada basis data maka dihasilkan tabel "ddd" memiliki nilai 3. Maka dapat disimpulkan bahwa terdapat 3 transaksi yang mengandung kedua buah item merde dan herxer.

4) Setelah menemukan jumlah transaksi yang mengandung merde dan herxer maka masukkan nilai ke dalam rumus support.

$$
\text { Support }=\frac{\text { JmlTransaksiMengandung } A \text { dan } B}{\text { TotalTransaksi }}=\frac{3}{20}=-0.15=15 \%
$$

Karena support adalah persentase maka 0.15 dikali 100 sehingga menjadi 15\%. Sedangkan 20 adalah jumlah transaksi yang ada dalam database, sehingga dapat disimpulkan bahwa ini terbukti dengan perhitungan secara manual.

5) Untuk mengetahui nilai confidence maka perlu mengetahui berapakah jumlah transaksi yang mengandung a (220440000) didalam basis data. Maka query yang digunakan adalah:

"SELECT COUNT ( DISTINCT no_nota) AS ddd FROM transaksi_apotik_detail

WHERE 
'220440000' '”.

Dari query ini dapat dilihat bahwa data yang akan dicari yaitu data yang memiliki kode obat „220440000" yaitu merde, selanjutnya ditampilkan sebagai bagian dari tabel „ddd" yaitu 6 .

6) Masukkan kedalam rumus confidence.

Support $=\frac{\text { JmlTransaksiMengandung Adan } B}{\text { TotalTransaksi }}=\frac{3}{6}=-0.5=50 \%$

Dari pembuktian ini didapat nilai confidence dari item merde dan herxer adalah 50\%. Dapat disimpulkan bahwa sistem yang bekerja pada form analisis ini terbukti akurat sebagaimana dengan percobaan perhitungan manual seperti yang telah dijabarkan.

\section{A. Simpulan}

\section{SIMPULAN DAN SARAN}

Berdasarkan hasil dari penelitian yang telah dilakukan, diketahui bahwa implementasi algoritma apriori dapat digunakan untuk mengidentifikasi obat yang kemungkinan dibeli bersamaan dengan obat lain, serta menunjukkan obat yang paling banyak terjual dan paling sedikit terjual berdasarkan himpunan kombinasi item. Hasil identifikasi sistem tersebut dapat digunakan untuk membantu pihak manajemen dalam menentukan persediaan obat dan merancang strategi pemasaran dengan cepat, tepat dan efisien.

B. Saran

Dalam upaya pengembangan dari penelitian ini maka penulis memberikan saran yakni perlu dilakukan perbandingan dengan algoritma lain, untuk menguji serta mendapatkan kesimpulan bahwa algoritma apa yang berkinerja baik untuk memproses dan menemukan suatu pola hubungan (asosiasi) antar item dari suatu basis data transaksi.

\section{REFERENSI}

[1] Dewantara, H., Santosa, P.B. dan Setyanto, N.W., 2013, Perancangan Aplikasi Data Mining Dengan Algoritma Apriori Untuk Frekuensi Analisis Keranjang Belanja Pada Data Transaksi Penjualan (Studi Kasus di Swalayan KPRI Universitas Brawijaya), Teknik Industri, Fakultas Teknik, Universitas Brawijaya, Malang.

[2] Amiruddin, Purnama, K.E. dan Purnomo M.H., 2007, Penerapan Association Rule Mining Pada Data Nomor Unik Pendidik Dan Tenaga Kependidikan Untuk Menemukan Pola Sertifikasi Guru, Teknik Elektro FTI, ITS, Surabaya.

[3] Setiawati, D.D., 2009, Penggunaan Metode Apriori Untuk Analisa Keranjang Pasar Pada Data Transaksi Penjualan Minimarket Menggunakan Java \& Mysql, Teknik Informatika, Universitas Gunadarma, Depok.

[4] Syaifullah, M.A., 2010, Implementasi Data Mining Algoritma Apriori Pada Sistem Penjualan, Teknik Informatika, STMIK AMIKOM, Yogyakarta.

[5] Ikhsan, M., Dahria, M. dan Sulindawaty, 2007, Penerapan Associaton Rule dengan Algoritma Apriori Pada Proses Pengelompokan Barang di Perusahaan Retail, Sistem Komputer, STMIK-Triguna Dharma, Medan. 